Advances in Gene Technology: The Genome and Beyond -

Structural Biology for Medicine (Proceedings of the 2002 Miami

Nature Biotechnology Winter Symposium)

TheScientificWorld 2002, 2(S2), 39-40

ISSN 1532-2246; DOI 10.1100/tsw.2002.20

\title{
PURIFICATION OF GST FUSION PROTEINS, ON-COLUMN CLEAVAGE, AND SAMPLE CLEAN UP
}

\author{
Jill A. Sigrell and Anna Heijbel \\ Amersham Pharmacia Biotech AB, SE-751 84 Uppsala, Sweden \\ anna.heijbel@eu.apbiotech.com
}

INTRODUCTION. Expression of recombinant proteins fused to the affinity tag Glutathione Stransferase (GST) allows fast and easy protein purification by chromatography on Glutathione Sepharose ${ }^{\mathrm{TM}}[1,2]$. This work, we purify six different human proteins all produced as fusions to GST and expressed in E. coli.

METHOD AND RESULTS. Four of the proteins are part of a structural genomics project, where the aim is to determine their 3-dimensional structures. Firstly, the proteins were produced on a small scale. Using a preprogrammed template on ÄKTA ${ }^{\mathrm{TM}}$ prime, the purification of these four proteins from cell extracts was quickly performed, making it possible to easily evaluate each protein's expression, purity, and stability. This information will, for each protein, enable a scaleup strategy for expression and purification that is required to produce enough homogenous material for structural studies.

The other two proteins, were expressed using two different pGEX vectors which introduce protease sites between the GST affinity tag and the target protein. With this approach pure, free target protein can be obtained in a straightforward way. The vector expressing hippocalcin, a member of the neurone-specific, calcium-binding protein family, has a PreScission ${ }^{\mathrm{TM}}$ protease site. By on-column cleavage using this GST tagged protease, $10 \mathrm{mg}$ of pure hippocalcin was obtained from $1 \mathrm{~g}$ of wet cells.

When expressing the SH2 domain from a phosphatase, a thrombin site was incorporated between the GST tag and the SH2 domain. Thrombin (a serine protease that can bind the synthetic inhibitor p-aminobenzamidine) could be completely removed after on-column cleavage by placing a HiTrap $^{\text {TM }}$ Benzamidine FF (high sub) column in series after the GSTrap ${ }^{\text {TM }}$ FF column. The removal of thrombin was verified with an activity assay using the substrate S-2238. From $1 \mathrm{~g}$ of wet cells, $5 \mathrm{mg}$ of pure SH2 domain was obtained.

SUMMARY. All recombinant proteins were purified using prepacked GSTrap FF columns. Removal of the GST tag using an appropriate protease was easily performed on column and additional affinity columns allowed cleaved target proteins to be eluted without contaminating proteases. 
ACKNOWLEDGEMENT. Dr. Kristina Bäckbro, Uppsala University, Uppsala, Sweden for GST-hippocalcin, Pharmacia Corporation, Stockholm, Sweden for SH2-GST and Martin Hammarström, Royal Institute of Technology, Stockholm, Sweden for GST-fused ORFs.

\section{REFERENCES}

1. Amersham Pharmacia Biotech (2001) GST Gene Fusion System Handbook.

2. Amersham Pharmacia Biotech (2001) The Recombinat Protein Handbook. 

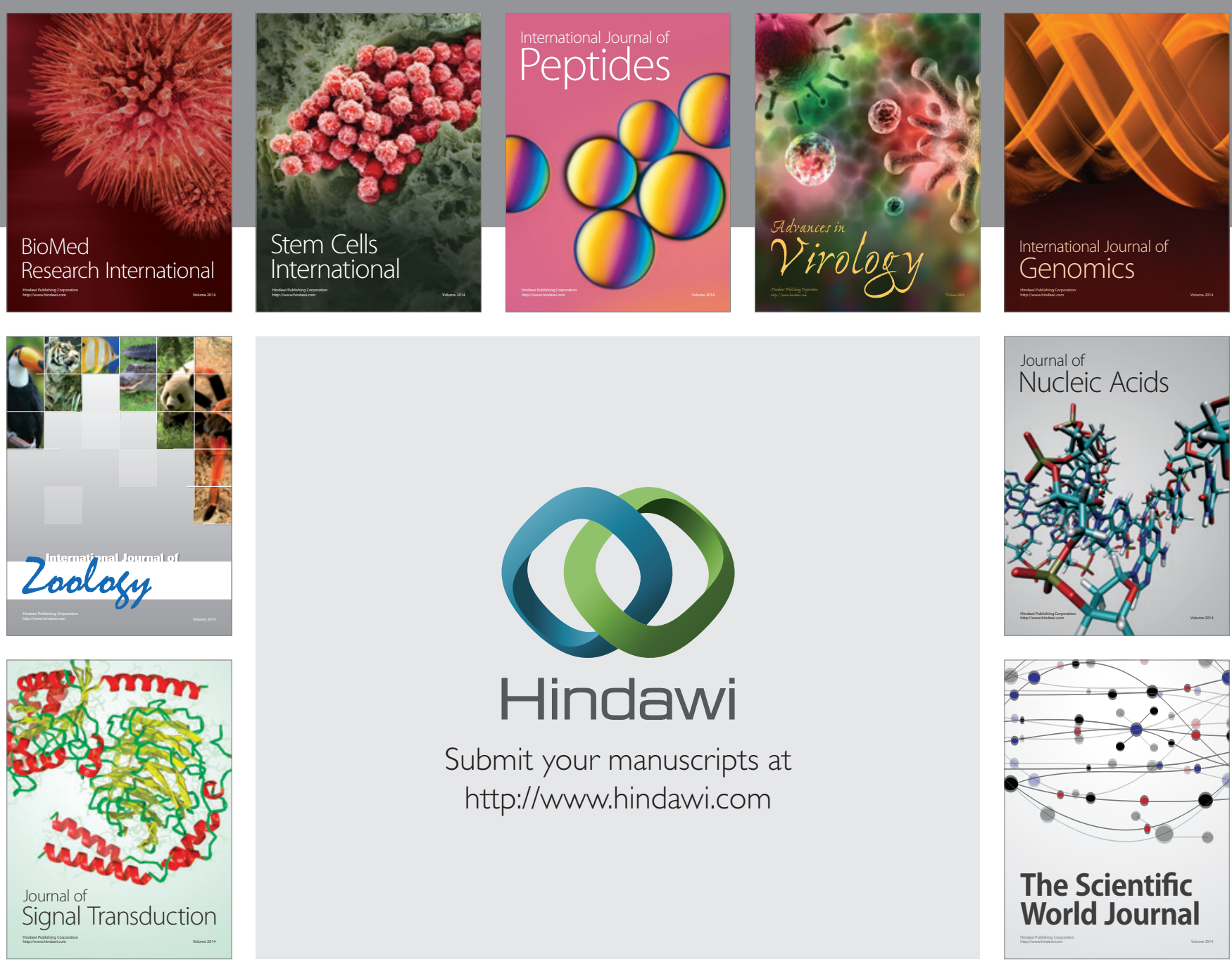

Submit your manuscripts at

http://www.hindawi.com
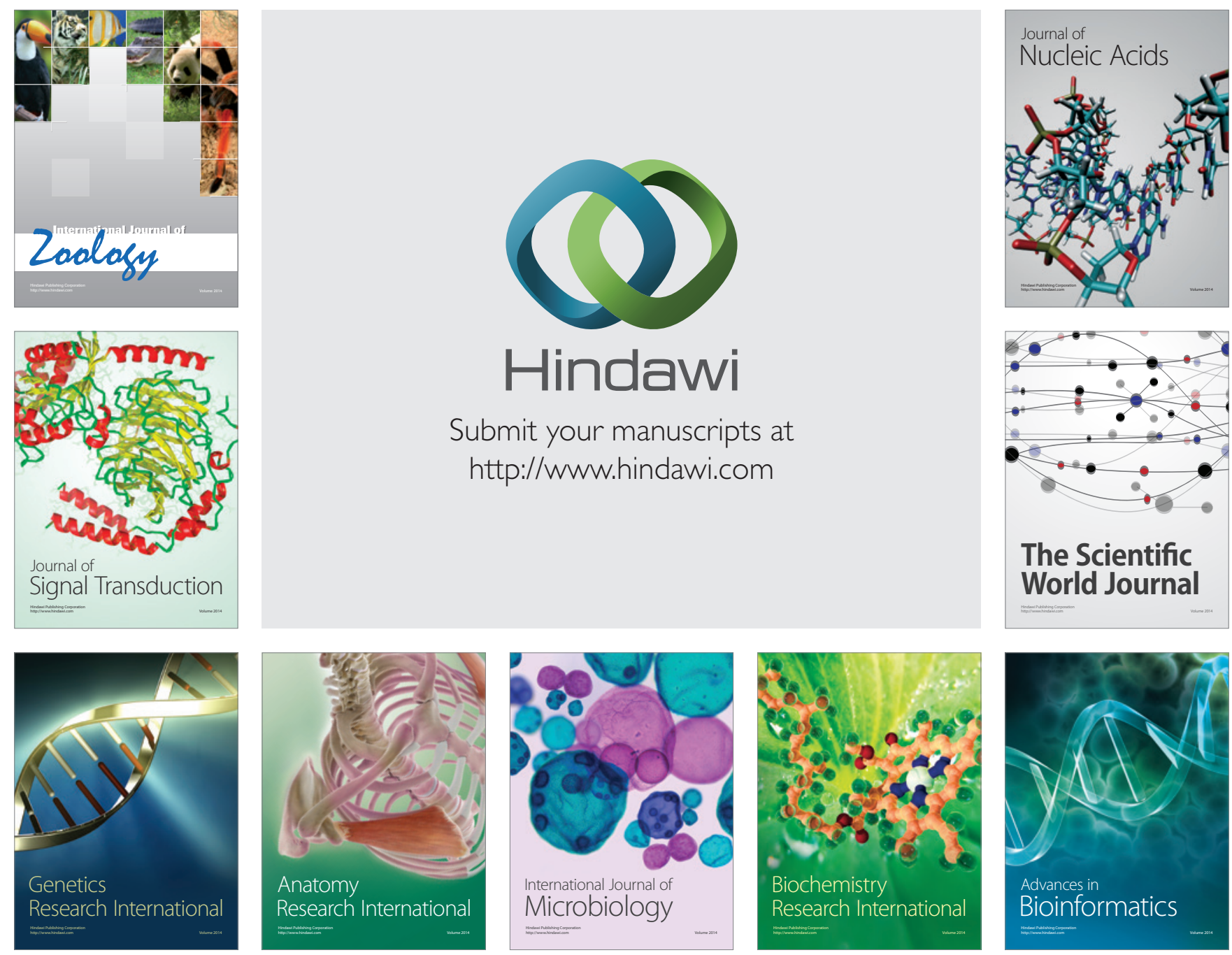

The Scientific World Journal
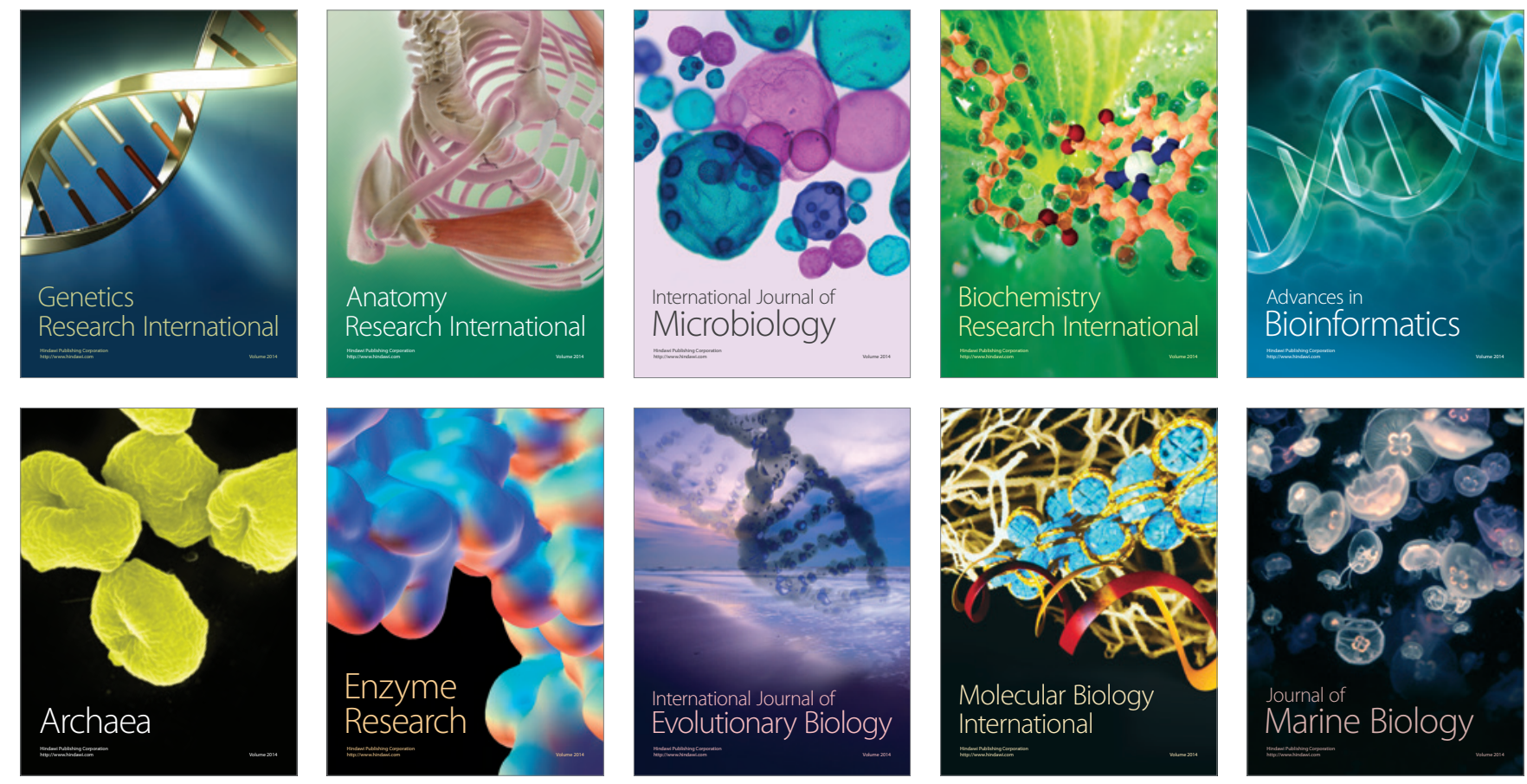